DOI: https://doi.org/10.31874/2309-1606-2021-27-1-7

УДК 17.022.1:37.091.4(477)«Макаренко»

\title{
Володимир Салій
}

\section{Проблема колективної моральної відповідальності: тематичний аналіз колективістської педагогіки Антона Макаренка}

Стаття ставить на меті усунути фундаментальний пробіл у дослідженнях колективної

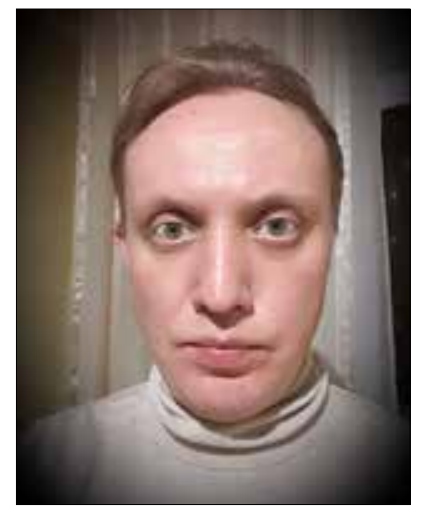
моральної відповідальності шляхом розвідування колективістської, на противагу домінуючій індивідуалістичній, точки зору на відношення окремого індивіда до колективного цілого. Зокрема, в ній представлено квалітативне тематичне дослідження ідей видатного українського педагога, методолога і теоретика освіти, засновника педагогічної школи Антона Семеновича Макаренка та його колективістської педагогіки як однієї із ключових освітніх парадигми, реалізованих у контексті радянської держави та суспільства. Аналіз концепцій колективного досвіду, комуністичної особистості, колективу, розподілу повноважень, відповідальності та дисципліни сприяє кращому розумінню власне природи індивідуальної та колективної моральної відповідальності. У той же час у статті стверджується, що результатом послідовного впровадження колективістського світогляду стає формування по суті дефектних незбалансованих відносин між індивідом та колективом. У радянському контексті такий дисбаланс проявляється у феноменах культу особистості та державного патерналізму. Як наслідок ототожнення відповідальності з дисципліною, індивідуальна особистість позбавляється моральної та утилітарної автономії, знецінюється та примусово асимілюється колективним цілим, що сприймається як найвище авторитетне джерело моральних суджень та єдиний розпорядник моральної відповідальності. Послідовне втілення колективістського світогляду в контексті радянського суспільства неминуче призводить до порушення рівноваги у співвідношенні індивідуального та колективного начала i, зрештою, виправдання будь-якого примусу та насильства з боку держави як такого колективу, що виконує найвищу піклувально-педагогічну функцію.

Ключові слова: колектив, колективізм, колективна моральна відповідальність, виховання, педагогіка.

(C) В. Салій, 2021 


\section{Вступ}

Принаймні з кінця 40-х років двадцятого століття дедалі ширше коло дослідників долучається до вивчення проблеми колективної моральної відповідальності, яка опиняється у центрі палких теоретичних дискусій та поступово виокремлюється у якості спеціального предмету філософського аналізу. Узагальнюючи значний об'єм попередніх наукових розвідок з даної тематики, у минулому році американське видавництво Routledge здійснило видання фундаментального Довідника колективної відповідальності (Routledge Handbook of Collective Responsibility), в якому представлена ціла гірлянда грунтовних, подекуди доволі заплутаних і часто взаємовиключних етико-філософських концепцій. Наявність такої множини тлумачень свідчить, по-перше, про відсутність елементарного консенсусу у літературі щодо визначення поняття колективної відповідальності, безпосередньо пов'язаного із такими його смислоутворюючими поняттями, як колектив та відповідальність, i, по-друге, про власне поступове зростання ролі та значимості колективної дії та колективних зобов'язань у найрізноманітніших сферах сучасного глобального людського співжиття.

У схематичному, найпростішому вигляді проблему колективної моральної відповідальності можна сформулювати наступним чином: «певна кількість людей зробила своїми спільними або сукупними діями дещо таке, що призвело до морально значущих результатів. Хто за це відповідальний і як слід розподіляти схвалення та звинувачення?» [Bazargan-Forward, \& Tollefsen 2020: 2]. При цьому треба зробити застереження, що західна філософська думка розглядає проблему колективної моральної відповідальності у контексті насамперед сучасного демократичного суспільства, в якому домінуючими $є$ індивідуалістичні цінності, а захист прав та свобод кожної окремої людини гарантується державою на найвищому політичному і юридичному рівнях. Навіть тоді, коли у якості об’єкта етичної оцінки автори обирають поведінку певної історичної локалізованої спільноти, - як, наприклад, це роблять К. Ясперс та Г. Арендт у своїх дослідженнях колективної провини німців за злочини нацистського режиму, тобто мова йде про ретроспективну або заміщувальну (vicarious) моральну відповідальність, - така поведінка розглядається, по-перше, під кутом її (не)відповідності певному набору базових, фундаментальних та універсальних моральних цінностей та, по-друге, з точки зору її наслідків для сучасного суспільства, зокрема й для сучасної освіти [Арендт 2013; Ясперс 1999]. Однак, незважаючи на велику кількість різноманітних наукових розробок у площині колективної відповідальності, у літературі практично відсутній будь-який системний аналіз цього явища з теоретичних позицій колективістської 
традиції, тобто такої, що визнає пріоритетність колективного цілого щодо окремого індивіда. У той же час $є$ підстави вважати, що вивчення колективістських підходів сприятиме істотному розширенню горизонтів розуміння феноменів колективності, колективу, співвідношення колективного та індивідуального, відповідальності, індивідуальної відповідальності та власне колективної відповідальності. Метою даної статті і $є$ започаткування такого напряму досліджень шляхом квалітативного тематичного аналізу особливостей імплементації колективістської традиції у контексті радянського суспільства, насамперед колективістської педагогіки Антона Семеновича Макаренко.

\section{Марксизм як теорія колективізму}

Утворення, існування та розвиток радянської держави та радянського суспільства можна розглядати, зокрема, як безпрецедентну спробу практичної реалізації основоположних ідей колективістської традиції у трактуванні співвідношення окремого індивіда та колективного цілого. За визначенням радянської Філософської енциклопедії, колективізм виступає тут у якості «одного з найважливіших принципів класової боротьби пролетаріату» та «всезагального принципу моральнісної поведінки людини, що відповідає пануючим соціальним відносинам» у соціалістичному та комуністичному суспільстві [Сентебов 1962: 563]. Ідеали колективізму були зафіксовані офіційно схваленим у СРСР лозунгом у формі заклику до єднання «пролетарів всіх країн» [Сентебов 1962: 564]. Основи такого колективістського світогляду розробляються ще в працях К. Маркса та Ф. Енгельса. На переконання останніх, саме завдяки майбутній колективній організації суспільного життя уможливлюється фундаментальна мета роз-речевлення особистісних сил та знищення поділу праці, що нібито й послугувало першопричиною формування відчуженого, вимушеного, неавтентичного, штучного об'єднання роз'єднаних між собою індивідів. Зокрема, з їхньої точки зору, наслідком поділу праці стало виникнення суспільних відносин як незалежної, самостійної, зовнішньої щодо індивіда сили, яка опосередковує його відношення з іншими індивідами та призводить до розколу між власне особистим та матеріальним життям індивіда, зумовленим його участю в певній галузі праці. «Відмінність індивіда як особистості від класового індивіда, [тобто] випадковий характер, який мають для індивіда його життєві умови, - як пояснюють К. Маркс та Ф. Енгельс, - з'являється лише разом з появою того класу, який сам $є$ продукт буржуазії. Тільки конкуренція і боротьба індивідів один з одним породжує і розвиває цей випадковий характер як такий. Тому при пануванні буржуазії індивіди здаються більш вільними, ніж вони були раніше, бо їхні життєві умови 
Володимир Салій. Проблема колективної моральної відповідальності...

$\epsilon$ випадковими для них; в дійсності ж вони, звичайно, менш вільні, бо $\epsilon$ більше підпорядкованими речовій силі» [Маркс, \& Энгельс 1955: 77]. При цьому К. Маркс та Ф. Енгельс проводять чітке розмежування між «дійсною» колективністю та її «позірними» формами. В умовах позірної, ілюзорної або сурогатної колективності, притаманної капіталістичному суспільству, - на кшталт держави, соціального класу та інших «недосконалих» різновидів соціальної спільноти, - має місце такий тип соціальних відносин, коли, по-перше, відбувається протиставлення колективу як цілого - індивідам як учасникам колективу та, по-друге, протиставлення одного колективу - іншим наявним колективам (наприклад, об’єднання одного соціального класу проти іншого). У позірному колективі особиста свобода окремих індивідів $\epsilon$ неминуче обмеженою, оскільки, з одного боку, останні об’єднуються в ньому не в якості індивідів, а лише в якості членів соціального класу, тобто «лише як середні індивіди, лише настільки, наскільки вони живуть в умовах існування свого класу», та, з іншого боку, оскільки можливості їхнього розвитку окреслюються власне «наявними продуктивними силами і формами спілкування» [Маркс, \& Энгельс 1955: 75-76]. Навпаки, спираючись на високорозвинуті продуктивні сили, прогресивний соціальний клас революційних пролетарів, як доводять К. Маркс та Ф. Енгельс, необхідно подолає суперечність між своїм особистим життям та зовнішніми, нав'язаними матеріальними умовами свого існування, тобто праці. Оскільки ж суперечність між особистістю окремого пролетаря та працею є глибоко вкоріненою в наявних суспільних відносинах, остільки її подолання спонукатиме пролетарів до знищення держави як такої «форми, в якій індивіди, що складають суспільство, раніше виражали себе як деяке ціле», та установлення контролю над суспільними відносинами як умовою «вільного розвитку і руху індивідів» [Маркс, \& Энгельс 1955: 77-78]. Це масштабне революційне соціальне перевлаштування нібито обумовить виникнення вже глобальної дійсної колективності, в якій «індивіди беруть участь як індивіди» та «знаходять свободу в своїй асоціації і за допомогою неї» [Маркс, \& Энгельс 1955: 75-76]. Отже, поза межами такого дійсного, власне соціального колективу будь-яка особиста свобода виявляється однобічною, випадковою та, зрештою, примарною, оскільки відокремленому індивіду бракує доступу до засобів, що забезпечували б всебічний, гармонійний розвиток його індивідуальних задатків [Маркс, \& Энгельс 1955: 75].

Подальший розвиток вищеокреслене вчення К. Маркса та Ф. Енгельса знаходить в ідеології, теорії та практиці соціал-демократичного руху в Росії наприкінці дев'ятнадцятого та на початку двадцятого століття. Зокрема, автори збірника статей під назвою Нариси філософії колективізму від 1909 року розглядають колективізм вже у якості основи 
цілісного пролетарського класового світогляду та ідейного знаряддя згуртування робітничого класу. А. Луначарський підкреслює спорідненість філософських учень Ф. Ніцше та К. Маркса через їхнє заперечення священних прав особистості та визнання права сильного нехтувати інтересами слабких задля реалізації принципу активного прогресу, наголошуючи, що саме К. Маркс запропонував адекватне розуміння кінцевої мети цього прогресу, а саме - максимального зростання продуктивних сил, що супроводжується утвердженням колективізму як вищої форми розвитку людської природи [Луначарський 1909: 240-241]. Охоплюючи сфери пізнання, практики та творчості, колективізм у його найзагальнішій формі проголошується «філософією праці та об’єднання», а також «теорією соціальної активності та активної соціальності» [От редакции 1909: 5-6]. Саме суспільство у якості певної «організованої активності» виступає автентичним суб'єктом пізнання, щодо якого діяльність окремої людини є лише «точкою прикладання соціальних сил» [Вернер 1909: 33]. Історичним завданням пролетаріату, на думку редакції збірника, виступає подолання соціальних суперечностей, що у свою чергу сприятиме утвердженню «пізнавальної єдності світу», в якому людство сприймається як «гігантська система співпраці людей у просторі і часі». «Мірою того, як пролетар піднімається все вище у своєму класовому розвитку, - наголошує редакція збірника, - він усе більше живе в колективі та разом з колективом, зливаючи свої прагнення з його інтересами, свою діяльність з його творчістю, свої переживання з його досвідом» [От редакции 1909: 5-6].

\section{Педагогічна система Антона Макаренка як втілення колективістського світогляду і методології колективізму}

У подальшому такі засади філософії колективізму імплементуються в педагогічній теорії та практиці радянської держави. Зокрема, педагогічна система А. Макаренко постає одним із найрельєфніших свідчень реалізації послідовного колективістського світогляду. Наріжним каменем цієї системи є поняття колективного досвіду як центрального фактору, що зумовлює як формування людської особистості в соціалістичному суспільстві в цілому, так і методи та наслідки їі виховання. «Досвід колективного життя, - стверджує А. Макаренко, - $є$ не лише досвід сусідства з іншими людьми, це дуже складний досвід доцільних колективних рухів, серед яких найпомітніше місце займають принципи розпорядження, обговорення, підпорядкування більшості, підпорядкування товариша товаришу, відповідальності та узгодженості» [Макаренко 1951j: 335]. 
Володимир Салій. Проблема колективної моральної відповідальності...

У своєму розгорнутому аналізі численних тематичних досліджень, які А. Макаренко наводить з метою більш наочного висвітлення засадничих принципів дитячого виховання у його відомій праці Книга для батьків, автор підкреслює насамперед роль колективного досвіду у тих чи інших недоліках індивідуального розвитку дитини. Наприклад, А. Макаренко робить наступний висновок у одному із таких тематичних досліджень: «за радянською фізіономією Колі і за його дитячою облудою прихована моральна порожнеча, відсутність будь-якого колективного досвіду, що в дванадцять років повинна мати кожна дитина. У таких випадках у дитини потреба набухає у відокремленій грі уяви без будь-якого зв'язку з потребами інших людей» [Макаренко 1951b: 43-44]. Саме поняття «колектив» та «колективізм» використовуються А. Макаренком для визначення стрижневих людських потреб, уявлень, поглядів та ідей, утворюючи концептуальне поле його методики виховної роботи. Завданням останньої проголошується селекція та розвиток людських потреб з метою забезпечення їхньої відповідності найвищому рівню моральнісної чистоти «безкласового» суспільства, що в свою чергу нібито має спонукати індивіда до подальшого морального вдосконалення. У цьому відношенні, з точки зору А. Макаренка, потреба виявляться морально виправданою настільки, наскільки вона $є$ «потребою колективіста» у значенні «людини, що пов'язана зі своїм колективом єдиною метою руху, єдністю боротьби, живим і безсумнівним відчуттям свого обов'язку перед суспільством» [Макаренко 1951b: 38].

Колективізм визначається А. Макаренко у якості «реальної солідарності людини з роботою і інтересами інших людей, з інтересами всього суспільства» [Макаренко 1951b: 393]. А колектив у загальному сенсі слова позначає кожну групу людей, пов'язаних спільним життям, інтересами, радощами чи горем [Макаренко 1951с: 335]. Причому у якості базових, елементарних осередків колективного життя радянського суспільства А. Макаренко виокремлює насамперед сім'ю, школу або виховальний заклад (колонію чи комуну) та педагогічний колектив [Макаренко 1951е, 318]. Таким чином основою теорії освіти А. Макаренка $\epsilon$ педагогічна методологія колективізму, що розглядає будь-які моральні та моральнісні цінності як такі, формування яких неминуче зумовлене колективним способом людського життя.

У свою чергу саме система виховання у поєднанні з суспільно-політичною чутливістю, згідно освітницької теорії А. Макаренка, покликані забезпечувати інтеріоризацію колективістських цінностей та формування «комуністичної» особистості 3 наймолодших років життя людини. Однак об'єктом виховання проголошується вже не сам індивід, а колектив, який нібито не перебуває у відношенні протилежності щодо першого, а лише співвідноситься з ним у відповідності з діалектичною 
тезою про співвідношення загального та окремого [Макаренко 1951j: 334]. Але мова не йде про виховання унікальної, гармонічної людської особистості як суб'єкта морального вдосконалення чи навіть просто чесної та доброї людини [Макаренко 1951j: 336]. Так, заперечуючи будьякі абстрактні ідеали освіти як непрактичні, А. Макаренко наголошує, що у контексті колективу відбувається «проектування» особистості «до останнього гвинтику» у процесі «педагогічного виробництва» на підставі суспільного замовлення [Макаренко 1951f: 441-442]. Серед провідних особистісних рис майбутньої «політично діяльної та відповідальної» людини А. Макаренко особливо підкреслює «самопочуття людини у колективі, характер ії̈ колективних зв'язків і реакцій, її дисциплінованість, готовність до дії та заторможення, здатність такту та орієнтування, принциповість та емоційно перспективне спрямування» [Макаренко 1951i: 474]. Відповідно, педагог виступає у ролі насамперед педагога-організатора, представника «учительської армії», зусилля якої зосереджується на забезпеченні виховної дисципліни та режиму, що виявляться однаково сприятливими як для впливу на окрему людину, так і колектив як ціле. У якості ж ознак правильного режиму визначаються такі, як доцільність, точність, спільність та визначеність [Макаренко 1951d: 40-42; 1951j: 334-337]. Грунтовність зазначених принципів виховання пояснюється в тому числі особливостями розвитку соціалістичної держави, яка нібито перебуває у стані перманентної боротьби з «ворогами» «безкласового» суспільства.

Для конкретної ілюстрації розуміння А. Макаренком специфіки поєднання колективного та індивідуального в межах освітньої практики можна розглянути його аналіз морально-виховальної дилеми, пов'язаної з намаганням певного вихователя приховати окремий факт вчиненої учнем крадіжки від учнівського колективу школи. 3 одного боку, уникнення відповідальності перед колективом виявиться шкідливим для морального розвитку самого учня як майбутнього члена соціалістичного суспільства. 3 іншого ж боку, таке рішення вихователя матиме негативні наслідки і для колективу як цілого: «У колективі сталася крадіжка, - пояснює А. Макаренко, - а вихователь вважає за можливе обійтися без мобілізації громадської думки з цього приводу. Він дозволяє класу думати що завгодно, підозрювати у крадіжці кого завгодно, в остаточному підсумку він виховує у класі повну байдужість до таких випадків; запитується, звідки візьметься у наших людей досвід боротьби з ворогами колективу, звідки прийде до них досвід пристрасті і пильності, яким чином колектив навчиться контролювати особистість? Ось якби вчитель передав випадок із крадіжкою на розгляд колективу, а я пропоную навіть більше - на рішення колективу, тоді кожен учень був би поставлений перед необхідністю активної участі у громадській бо- 
Володимир Салій. Проблема колективної моральної відповідальності...

ротьбі, тоді вчитель отримав би можливість розгорнути перед класом якусь моральну картину, дати дітям також і позитивні креслення правильного вчинку. I кожен учень, який пережив емоцію рішення і засудження, тим самим долучився б до досвіду моральнісного життя» [Макаренко 1951: 332j]. Інакше кажучи, завданням системи виховання постає організація колективного досвіду, наявність якого вже сама по собі зумовлює розширене тлумачення відповідальності, коли кожна окрема людина відповідає не лише за власні вчинки, а й за вчинки «своїх товаришів», інших учасників колективу [Макаренко 1951j: 336].

\section{Визначення колективу Антоном Макаренком}

При цьому унікальність освітницьких розробок А. Макаренка полягає, зокрема, у системному впровадженні соціально-центричного бачення колективу у якості найдосконалішої конкретно-історичної форми співіснування, об'єднання та співпраці індивідів. Будь-які спроби окреслення критеріїв колективності шляхом систематизації логічних понять, як показує А. Макаренко, неминуче призводять до редукціоністського витлумачення колективу у відповідності з однією чи кількома випадковими, штучними властивостями, що в кінцевому підсумку означатиме відмову від класифікації та визначення колективу лише і тільки у якості певної механічної суми індивідів (на кшталт складних чи простих, довготривалих чи тимчасових колективів тощо). Проте так само шкідливими виявляються намагання побудувати класифікацію колективів на основі певних особистісних функцій (взаємодії, реакції тощо), оскільки результатом такого підходу буде біологізація феномену колективності, коли у значенні колективу може виступати ціла низка явищ, об'єднаних за найзагальнішими ознаками, таких як держави, суспільства, вуличні натовпи, мітинги, зібрання віруючих, групи дітей, що беруть участь у спільній грі, пасажири трамваю тощо [Макаренко 1951f: 446-448]. «Наша наукова думка, - зазначає А. Макаренко, узагальнюючи наявні на той час соціологічні, педологічні та педагогічні трактування колективу, - повинна не дедукувати випадкові комбінації загальнологічних ознак, а фотографувати дійсну схему соціальних явищ, на отриманих знімках розрізняти принципи поділу та об'єднання, а найважливіше - зі звірення двох розділених часом знімків робити висновки про процеси і тенденції зміни, зростання, падіння та ін.» [Макаренко 1951f: 447]. Саме глобальні еволюційні соціальні перетворення та поступова зміна характеру соціальних угруповань в межах кожного локалізованого суспільства сприяють виникненню, формуванню, утвердженню та поширенню колективної єдності як реального, конкретно-історичного явища соціального життя. Згідно такого підходу, позначення тієї чи ін- 
шої групи індивідів як певного колективу зумовлюється лише і тільки «специфічною соціальністю ознак» такої групи [Макаренко 1951f: 448]. Характеристика А. Макаренком колективу як насамперед соціального явища, що зумовлене своєрідністю саме людської природи та людської діяльності, уможливлює конкретніше його розуміння.

На відміну від натовпу чи простої множини індивідів, колектив, у відповідності до творчої спадщини А. Макаренка, виступає живим соціальним організмом, утвореним на добровільних засадах, що об'єднує певну «контактну сукупність» людей, які беруть участь в організованому виконанні різноманітних суспільно-корисних завдань, коли має місце (i) спільна мета, спільна діяльність та спільна організація діяльності; (ii) рівна участь усіх членів; (iii) пріоритетність колективного цілого щодо окремого індивіда; (iv) система повноважень; (v) точне визначення функцій окремих осіб та органів колективу; та (vi) чітке окреслення і невідворотність персональної та колективної відповідальності [Макаренко 1951e: 229; 1951: 448-449; 1951j: 334; 1951h: 207; 1951d: 83]. Причому визначення колективу просто у якості різновиду групової діяльності матиме ознаки редукціонізму. Адже своєрідність колективу як якісно вищої форми об’єднання людей щодо групи полягає насамперед у його соціальній направленості. Наприклад, подібно до колективу, торгова компанія, як правило, теж утворюється на добровільних засадах та передбачає співпрацю своїх учасників, але є суто груповим об'єднанням, оскільки діяльність такої компанії проводиться на основі агресивноспоживацького ставлення до дійсності, до інших соціальних груп та до людства в цілому [Макаренко 1951f: 448-449]. Тут варто згадати вже розглянуте вище зауваження К. Маркса та Ф. Енгельса щодо «позірної колективності» або такої, що протиставляє себе, з одного боку, як самостійне ціле - індивідам, які $є$ його складовими частинами, та, з іншого боку, як одна соціальна спільнота - іншим наявним соціальним спільнотам. На противагу позірній колективності, колектив у А. Макаренка постає як власне соціальна форма відношення індивіда до інших індивідів, яка є одночасно і відображенням і утвердженням універсальної єдності всього людства на основі співпраці.

Однак, концептуалізація колективу передбачає необхідність розуміння як характеру співвідношення індивідів всередині певного колективу, так і природи залежностей між різними колективами в межах конкретного локалізованого суспільства та загальнолюдської спільноти в цілому. Щодо характеристики взаємостосунків всередині колективу освітницька теорія А. Макаренка передбачає, по-перше, особливу систему повноважень та, по-друге, систему персональної та колективної відповідальності. «Там, де є організація колективу, - доводить А. Макаренко, - там є органи колективу, там є організація уповноважених осіб, довіре- 
Володимир Салій. Проблема колективної моральної відповідальності...

них осіб колективів, а питання ставлення товариша до товариша - це не питання дружби, не питання кохання, не питання сусідства, а це питання відповідальної залежності» [Макаренко 1951h: 207]. 3 одного боку, формальна рівність між членами колективу забезпечується їх спільною участю у роботі колективу та спільною відповідальністю за результати цієї роботи [Макаренко 1951h: 207]. 3 іншого боку, збалансоване функціонування колективу як цілого є результатом цілеспрямованих зусиль низки колективних органів, серед яких А. Макаренко виокремлює (i) загальне зібрання комуни, (ii) раду як центральний колегіальний орган самоуправління та (iii) первинні колективи. А ефективна діяльність зазначених органів колективу передбачає вже відношення не рівності, а підпорядкування одних учасників колективу іншим учасникам шляхом обрання уповноважених осіб. Останні обираються зі складу кожного первинного колективу загальним зібранням усіх членів колективу та відіграють роль довірених командирів чи бригадирів своїх низових осередків, реалізуючи їх представництво у раді як центральному керівному органі колективу [Макаренко 1951d: 20-26; 1951е: 253-258]. При цьому саме уповноважені особи несуть персональну відповідальність за діяльність своїх первинних колективів, а та уповноважена особа, яка в даний момент перебуває на чергуванні, виступає одноосібним втіленням влади всього колективу та виконує найширші управлінські функції. Зокрема, вона має право віддавати беззаперечні накази будь-якому учаснику колективу, її слова заборонено піддавати сумніву, а черговий рапорт не підлягає перевірці [Макаренко 1951е: 232-233]. Саме така система повноважень, на переконання А. Макаренка, гарантує максимальну згуртованість колективу як цілого та сприяє формуванню організованих, узгоджених взаємостосунків індивідів всередині колективу.

\section{Відповідальність у колективі згідно педагогічної теорії Антона Макаренка}

Цілком закономірно, що, як у рамках колективу, утвореного на основі імплементації вищеокреслених атрибутів, так і в межах теорії освіти А. Макаренка загалом, поняття відповідальності не набуває якогось першочергового значення у якості самостійної, цілісної морально-етичної категорії та нормативно-регулюючої складової автономної людської поведінки. Власне кажучи, система відповідальності описується А. Макаренком насамперед у вигляді певного комплексу виховничо-дисциплінарних вправ, прийомів, методик та заходів, що запроваджуються та функціонують для, по-перше, досягнення вищого рівня єдності, згуртованості, «зпаяності» та, в кінцевому підсумку, продуктивності взаємостосунків всередині даного локалізованого колективу та, по-друге, 
формування «організованого відношення членів одного колективу до членів іншого колективу», тобто з ширшою метою виховання певного базового набору елементарних навичок колективної співпраці, що визначаються як необхідні для адекватної участі індивіда в інших колективах та суспільному житті як такому [Макаренко 1951e: 253; 1951h: 207]. Центральними у даному разі виступають організаторські здібності, оскільки у процесі колективної праці «колектив звикає вимагати відповідальності не тільки від кожного окремого працівника, але і від кожного комунара як організатора» [Макаренко 1951h: 199]. Саме ж поняття відповідальності у широкому сенсі слова формулюються А. Макаренком у значенні простої «здатності орієнтування», тобто «відчуття свого або чужого» та «здатності розбиратися в навколишньому середовищі» [Макаренко 1951g: 452]. При цьому А. Макаренко виокремлює як персональну, так і колективну відповідальність, але не в якості самостійних морально-етичних концепцій, а лише у вигляді відмінних, різнорівневих виховничо-дисциплінарних підходів. Наприклад, коли мова йде про застосування певних дисциплінарних санкцій щодо такого первинного колективу, який демонструє недостатню ефективність у своїй роботі, А. Макаренко розмірковує над необхідністю накладання як індивідуального, так і групового покарання. Втім, він рекомендує зрештою уникати колективних санкцій, оскільки така форма покарання, на його думку, «об'єднує порушників, вже раніше об'єднаних у самому порушенні» [Макаренко 1951d: 50]. У той же час А. Макаренко наполягає на запровадженні колективної відповідальності або притягнення до відповідальності уповноваженого первинного колективу у таких спеціальних випадках, які стосуються псування чи недбалого ставлення до майна, коли встановити конкретних винуватців не виявляється можливим [Макаренко 1951d: 58-59]. Узагальнюючи вищесказане, витлумачена з подібних колективістських позицій відповідальність постає не як система певних індивідуальних ціннісно-нормативних орієнтирів, уявлень, поглядів чи ідей щодо універсальних принципів людської поведінки та механізмів моральної оцінки конкретних ситуацій, а насамперед як почуття відповідальності, зумовлене єдністю колективного досвіду та усвідомленням взаємозалежності індивідів як співучасників певного колективного об'єднання, а також - глибинного та беззаперечного зв'язку своїх інтересів та потреб з інтересами та потребами колективу як цілого, конкретного суспільства та всієї загальнолюдської спільноти.

Зовнішнім же способом вираження цього почуття відповідальності виступає дисципліна, формуючи свого роду чуттєвий вимір відповідальності. Причому, з одного боку, дисципліна трактується А. Макаренком не як метод, а як «останній підсумок» всієї діяльності колективу. «Дисципліна, - пише він, - це обличчя колективу, його голос, його краса, 
Володимир Салій. Проблема колективної моральної відповідальності...

його рухливість, його міміка, його переконаність. Все, що є в колективі, в кінцевому рахунку, набуває форми дисципліни» [Макаренко 1951е: 261]. Дисципліна поєднує у собі чітке та «спільне для всіх розуміння - як слід вчинити, з ясною, абсолютно точною зовнішньою формою, яка не допускає суперечок, розбіжностей, заперечень, зволікань, балаканини» [Макаренко 1951е: 261]. 3 іншого боку, саме дисципліна, як переконує А. Макаренко, виступає виявленням громадсько-політичного «самопочуття» вже окремого індивіда в соціалістичному суспільстві [Макаренко 1951е: 262]. Отже, відповідальність колективіста і в якості окремого індивіда, і як члена колективу не передбачає формування певних механізмів критичної моральної оцінки конкретних вчинків, а є лише доцільним відображенням і втіленням зовнішніх вимог, норм, установок та тенденцій колективного співжиття.

На практиці ж заміна реальної освіти у власному сенсі слова системою колективістської педагогіки, підміна автономних індивідуальних морально-ціннісних орієнтирів поняттям колективної доцільності та витлумачення відповідальності у якості почуття відповідальності або дисципліни, що є одночасно і методом і результатом педагогічного процесу та внутрішнім відображенням організації колективної співпраці, не сприяє імплементації окресленого К. Марксом та Ф. Енгельсом ідеалу гармонійного та всебічного розвитку індивідуальних задатків кожної окремої людської особистості. Навпаки, у контексті радянського суспільства така виховально-дисциплінарна освітницька парадигма призводить насамперед до утворення «відчуженої відповідальності» шляхом, по-перше, радикального знецінення ролі та значення окремої, унікальної людської особистості та, по-друге, формування культу видатних особистостей, зокрема культу особистості Й. Сталіна [Гефтер 1988: 303]. При цьому в моральній свідомості колективіста немає інструментарію для вирішення цієї етичної дилеми. Як наслідок, колективісти змушені грати у свого роду «гру у хованки зі Сталіном, неправомірно відокремлюючи себе від нього» [Гефтер 1988: 306]. 3 одного боку, апологети особистості Й. Сталіна апелюють до колективної відповідальності знеособлених суспільних сил, що брали участь у розбудові нового комуністичного суспільства; з іншого боку, викривачі Й. Сталіна акцентують увагу на його індивідуальній відповідальності, приписуючи йому безпрецедентні можливості історичного передбачення та суспільно-політичного впливу, що фактично забезпечує реставрацію культу його особистості [Лапкин, \& Пантин, 1989: 328]. Свого часу, іронізуючи над обережною формулою утилітарного егоїзму Д. Бентама, А. Луначарський зробив наступний висновок: «живої солідарності немає у міщанина, він не почуває себе частиною великого 'Ми'» [Луначарський 1909: 245]. Осмислюючи ж феномен форсованої індустріалізації, «дисциплінарного деспотизму» 
та масових політичних репресій $30-\mathrm{x}$ років минулого століття, Е. Соловйов стверджує вже без іронії: «оскаженіло-колективістське 'ми' ... просто заміщує нормальне людське 'я', хоча й не може усунути його як суб’єкт мовлення: патерналістське мислення піднімається до останнього, нестерпного і тим не менше абсолютно логічного парадоксу: мене заарештовують, топчуть, можливо, знищують, щоб мене ж охоронити і виховати» [Соловьев 1990: 193-194). По суті, заперечення моральної та утилітарної автономії індивіда сприяє «відродженню патріархально-казармової концепції навчання як муштри» [Соловьев 1990: 193, 210-211]. Отже, послідовне втілення колективістського світогляду в контексті радянського суспільства неминуче призводить до порушення рівноваги у співвідношенні індивідуального та колективного начала і, зрештою, виправдання будь-якого примусу та насильства з боку держави як такого колективу, що виконує найвищу піклувально-педагогічну функцію.

\section{Висновки}

На прикладі квантитативного аналізу колективістської педагогіки Антона Семеновича Макаренка продемонстровано, що вивчення колективістських підходів сприяє істотному розширенню горизонтів розуміння феноменів колективності, колективу, співвідношення колективного та індивідуального, відповідальності, індивідуальної відповідальності та власне колективної відповідальності. Колективістська педагогіка Макаренка базується на філософії марксизму, згідно якої поза межами дійсного колективу будь-яка особиста свобода виявляється однобічною, випадковою та, зрештою, примарною, оскільки відокремленому індивіду бракує доступу до засобів, що забезпечували б всебічний, гармонійний розвиток його індивідуальних задатків. Колектив транслює індивіду певний соціальний досвід, однак він не завжди є суспільно корисним і прийнятним для особистості. Для гармонійного узгодження індивідуального і колективного необхідна спільна виробнича практика, тобто незаперечно важлива спільна справа, якій індивіди підкоряються задля спільного і власного блага. Крім того, важлива особиста участь кожного у прийнятті рішень щодо функціонування трудового колективу: ефективна діяльність управлінських органів колективу передбачає вже відношення не рівності, а підпорядкування одних учасників колективу іншим учасникам шляхом обрання уповноважених осіб. Освітницька теорія А. Макаренка передбачає, по-перше, особливу систему повноважень та, по-друге, систему персональної та колективної відповідальності. Саме така система повноважень, на переконання А. Макаренка, гарантує максимальну згуртованість колективу як цілого та сприяє формуванню організованих, узгоджених взаємостосунків ін- 
дивідів всередині колективу. Витлумачена з подібних колективістських позицій відповідальність постає не як система певних індивідуальних ціннісно-нормативних орієнтирів, уявлень, поглядів чи ідей щодо універсальних принципів людської поведінки та механізмів моральної оцінки конкретних ситуацій, а насамперед як почуття відповідальності, зумовлене єдністю колективного досвіду та усвідомленням взаємозалежності індивідів як співучасників певного колективного об'єднання, а також - глибинного та беззаперечного зв'язку своїх інтересів та потреб з інтересами та потребами колективу як цілого, конкретного суспільства та всієї загальнолюдської спільноти.

\section{Посилання:}

Арендт, Х. (2013). Ответственность и суждение. Москва: Издательство Института Гайдара.

Вернер, И. (1909). Наука и философия. Очерки философии коллективизма. Сборник первый. Санкт-Петербург: Издание товарищества «Знание». 9-34.

Гефтер, М. (1988). Сталин умер вчера. Афанасьев, Ю. Н. (ред.). Иного не дано. Москва: Прогресс. 297-323.

Луначарский, А. (1909). Мещанство и индивидуализм. Очерки философии коллективизма. Сборник первый. Санкт-Петербург: Издание товарищества «Знание». 219-350.

Лапкин, В. и Пантин, В. (1989). Что такое сталинизм? Кобо, Х. (ред.) Осмыслить культ Сталина. Москва: Прогресс. 327-336.

Макаренко, А. С. (1951a). Выступления по вопросам семейного воспитания. Макаренко, А. С. Сочинения, том 4. Москва: Издательство Академии педагогических наук РСФСР. 431-510.

Макаренко, А. С. (1951b). Книга для родителей. Макаренко, А. С. Сочинения, том 4. Москва: Издательство Академии педагогических наук РСФСР. 11-340.

Макаренко, А. С. (1951c). Лекции о воспитании детей. Макаренко, А. С. Сочинения, том 4. Москва: Издательство Академии педагогических наук РСФСР. 341-430.

Макаренко, А. С. (1951d). Методика организации воспитательного процесса. Макаренко, А. С. Сочинения, том 5. Москва: Издательство Академии педагогических наук РСФСР. 9-106.

Макаренко, А. С. (1951е). Некоторые выводы из педагогического опыта. Макаренко, А. С. Сочинения, том 5. Москва: Издательство Академии педагогических наук РСФСР. 225-320.

Макаренко, А. С. (1951f). Опыт методики работы детской трудовой колонии. Макаренко, А. С. Сочинения, том 5. Москва: Издательство Академии педагогических наук РСФСР. 439-462.

Макаренко, А. С. (1951g). О «Книге для родителей». Макаренко, А. С. Сочинения, том 4. Москва: Издательство Академии педагогических наук РСФСР. 437-454.

Макаренко, А. С. (1951h). Проблемы школьного советского воспитания. Макаренко, А. С. Сочинения, том 5. Москва: Издательство Академии педагогических наук РСФСР. 105-224. 
Макаренко, А. С. (1951i). Художественная литература о воспитании детей. Макаренко, А. С. Сочинения, том 5. Москва: Издательство Академии педагогических наук РСФСР. 338-367.

Макаренко, А. С. (1951j). Цель воспитания. Макаренко, А. С. Сочинения, том 5. Москва: Издательство Академии педагогических наук РСФСР. 325-337.

Маркс, К. и Энгельс, Ф. (1955). Немецкая идеология. Маркс, К. и Энгельс, Ф. Сочинения, $m .3$, издание 2-е. Москва: Государственное издательство политической литературы. 7-544.

От редакции. (1909). Очерки философии коллективизма. Сборник первый. СанктПетербург: Издание товарищества «Знание». 3-6.

Сентебов, Л. (1962). Коллективизм. Философская энциклопедия, т. 2. Москва: Государственное издательство «Советская энциклопедия». 563-565.

Соловьев, Э. Ю. (1990). Правовой нигилизм и гуманистический смысл права. Мудрагей, В.И. и Усанов, В. И. (сост.) Квинтэссенция: Философский альманах. Москва: Издательство политической литературы. 162-235.

Ясперс, К. (1999). Вопрос о виновности. Вопрос о виновности. О политической ответственности Германии. Москва: Прогресс. 15-105.

Bazargan-Forward, S. \& Tollefsen, D. (2020) Introduction. Bazargan-Forward, S. \& Tollefsen, D. (ed.). The Routledge Handbook of Collective Responsibility. New York: Routledge, 1-3.

\section{References:}

Arendt, H. (2013). Responsibility and judgment. Moscow: Gaidar Institute Publishing House. [In Russian].

Bazargan-Forward, S. \& Tollefsen, D. (2020). Introduction. Bazargan-Forward, S. \& Tollefsen, D. (ed.) The Routledge Handbook of Collective Responsibility. New York: Routledge, $1-3$.

Gefter, M. (1988). Stalin died yesterday. Afanasiev Y. N. (ed.). No other way. Moscow: Progress. [In Russian]. 297-323.

Jaspers, K. (1999). The question of guilt. The question of guilt. On the political responsibility of Germany. Moscow: Progress. [In Russian]. 15-105.

Lunacharsky, A. (1909). Philistinism and individualism. Essays on the philosophy of collectivism. The first collection. St. Petersburg: Edition of the Association «Knowledge», 1909. [In Russian]. 219-350.

Lapkin, V. \& Pantin, V. (1989). What is Stalinism? Kobo, H. (ed.) Comprehending the cult of Stalin. Moscow: Progress. [In Russian]. 327-336.

Makarenko, A.S. (1951a). Presentations on the issues of family education. Works, 4. Moscow: Publishing house of the RSFSR Academy of Pedagogical Sciences. [In Russian]. 431-510.

Makarenko, A.S. (1951b). Book for parents. Works, 4. Moscow: Publishing house of the RSFSR Academy of Pedagogical Sciences. [In Russian]. 11-340.

Makarenko, A.S. (1951c). Lectures on parenting. Works, 4. Moscow: Publishing house of the RSFSR Academy of Pedagogical Sciences. [In Russian]. 341-430.

Makarenko, A.S. (1951d). Methodology for organizing the educational process. Works, 5. Moscow: Publishing house of the RSFSR Academy of Pedagogical Sciences. [In Russian]. 341-430. 
Makarenko, A.S. (1951e). Some conclusions from pedagogical experience. Works, 5. Moscow: Publishing house of the RSFSR Academy of Pedagogical Sciences. [In Russian]. 225-320.

Makarenko, A.S. (1951f). Experience in the methodology of the work of a children's labor colony. Works, 5. Moscow: Publishing house of the RSFSR Academy of Pedagogical Sciences. [In Russian]. 439-462.

Makarenko, A.S. (1951g). About the «Book for parents». Works, 4. Moscow: Publishing house of the RSFSR Academy of Pedagogical Sciences. [In Russian]. 437-454.

Makarenko, A.S. (1951h). Problems of Soviet school education. Works, 5. Moscow: Publishing house of the RSFSR Academy of Pedagogical Sciences. [In Russian]. 105-224.

Makarenko, A.S. (1951i). Fiction about the upbringing of children. Works, 5. Moscow: Publishing house of the RSFSR Academy of Pedagogical Sciences. [In Russian]. 338-367.

Makarenko, A.S. (1951j). The purpose of education. Works, 5. Moscow: Publishing house of the RSFSR Academy of Pedagogical Sciences. [In Russian]. 325-337.

Marx, K. and Engels, F. (1955). German ideology. Works, 3, 2nd edition. Moscow: State Publishing House of Political Literature. [In Russian]. 7-544.

From the editors. (1909). Essays on the philosophy of collectivism. The first collection. St. Petersburg: Edition of the Association «Knowledge». [In Russian]. 3-6.

Sentebov, L. (1962). Collectivism. Philosophical Encyclopedia, 2. Moscow: State Publishing House «Soviet Encyclopedia». [In Russian]. 563-565.

Soloviev, E. Yu. (1990). Legal nihilism and the humanistic meaning of law. Mudragei, V.I. and Usanov, V.I. (comp.) Quintessence: Philosophical Almanac. Moscow: Publishing house of political literature. [In Russian]. 162-235.

Werner, I. (1909). Science and philosophy. Essays on the philosophy of collectivism. The first collection. St. Petersburg: Edition of the Association «Knowledge». [In Russian]. 9-34.

\section{Volodymyr Salii. The Problem of Collective Moral Responsibility: Qualitative Case Study of Anton Makarenko's Collectivist Pedagogy}

The article seeks to address a fundamental gap in collective moral responsibility research by exploring a collectivist rather than the dominating individualist perspective on the relationship between a private individual and the collective whole. In particular, it presents a qualitative case study of ideas of outstanding Ukrainian teacher, methodologist and theorist of education, founder of the pedagogical school Anton Semenovych Makarenko and his collectivist pedagogy as a major educational paradigm implemented within the context of the Soviet state and society. The analysis of the concepts of collective experience, communist personality, collective, distribution of powers, responsibility, and discipline contributes to a better understanding of the nature of individual and collective moral responsibility. At the same time, the article argues that a consistent implementation of the collectivist worldview results in an essentially flawed misbalanced relationship between an individual and the collective of people. In the Soviet context, such misbalance is evidenced in the phenomena of the cult of personality and state paternalism. As a consequence of identifying responsibility with discipline, the individual personality is deprived of its moral and utilitarian autonomy, devalued, and forcibly assimilated by the collective whole perceived as 
the highest authoritative source of moral judgement and the sole distributor of moral responsibility. Consistent implementation of the collectivist worldview in the context of Soviet society inevitably leads to an imbalance in the relationship between individual and collective principles and, ultimately, the justification of any coercion and violence by the state as such a team performing the highest guardianship and pedagogical function.

Keywords: collective, collectivism, collective moral responsibility, education, pedagogy.

Володимир Салій - аспірант кафедри етики, естетики та культурології Київського національного університету імені Тараса Шевченка.

E-mail: salii.vl@gmail.com

https://orcid.org/0000-0002-9297-3285

Volodymyr Salii - graduate student of the Department of Ethics, Aesthetics and Cultural Studies of the Taras Shevchenko National University of Kyiv.

E-mail: salii.vl@gmail.com

https://orcid.org/0000-0002-9297-3285 